Rizzo Rosalba, Professor of English and Translation ORCID: 0000-0001-5676-2758

Fragomeni Fabio, $\mathrm{PhD}$, University of Messina (Italy), P.ZZA XX Settembre, 1, Messina ORCID: 0000-0002-1455-0033

\title{
LANGUAGE COMPETENCES OF A SPECIALIST IN THE CONDITIONS OF GLOBALIZATION
}

This article aims to analyse the importance of language skills in the era of globalization, which has distinguished the economic and social system in recent years with frequent and rapid changes, influence the world of work and life at different levels. In this new scenario, in it is necessary for everyone to continuously update their skills and acquire new ones, in order to adapt to change and provide the responses expected from the labour market.

Keywords: Language competence, language training, globalization, business.

Рицо Розальда, Фрагомені Фабіо. Мовні компетенцї спеціаліста в умовах глобалізації.

Ця стаття має на меті проаналізувати значення мовних навичок в епоху глобалізації, яка останніми роками вирізняе економічну та соціальну систему частими та швидкими змінами, впливає на праці та життя на різних рівнях. У иъьому новому сценарії необхідно, щуоб кожен постійно оновлював свої навички та здобував нові, щоб адаптуватися до змін та забезпечити виклики ринку прачі.

Ключові слова: мовна компетентність, мовна підготовка, глобалізація, бізнес.

\section{Relevance of research topic}

Since 2000, the development of the knowledge-based society has led to a growing demand for both personal and professional skills to meet the complex new challenges. Here too, skills are not acquired once and for all, but skills to be constantly updated and rapidly evolving, in order to live and work successfully in society.

The new context also requires reviewing the organization of education at school (Morin, 2000), the methodological and didactic choices and, above all, the training of workers. Today, there is an increasing demand that schools promote the 
development of skills that are visible, verifiable and in line with the needs of society. It is therefore necessary for the school to promote the development of general skills in the main cultural, linguistic, mathematical, scientific and technological axes in its learners, starting from the school of infancy, historical and social, as well as key competences for lifelong learning (Risoluzione UE, 2006).

This need for renewal, substantial and comprehensive of our education system, is also supported by reading the OECD 2010 Report which highlights the critical aspects of Italian education system, starting with the high rates of early school leaving, setting out the priorities for action. It is also necessary to give a strategic role to guidance throughout life because of its central role in combating early school leaving and educational failure for two reasons in particular:

- for the pathological consequences that a bad or wrong orientation has on the education system and for the negative consequences on the economic-productive system;

- for problematic effects on the evolution of individual stories referring to the training, work, social aspect.

The new social and economic emergencies and new educational frontiers requires actions at all levels of education in order to support each young person in taking on a coherent choice and decision. This vision completely changes the mission of the education compared to the traditional model.

Formulation of the problem. As can be seen, the different social, economic and cultural scenarios give special attention to the term «competence» and to the place it occupies in the new training model.

But what do we mean by «competence»? Actually, different meanings are attributed to this term by scholars. Competence can be understood, for example, in the sense of «potentiality» inherent in a subject, but it can also be understood as «performance», which an entity must provide in relation to a task to be performed.

The meaning to which we prefer to refer is that of «ability of the subject/person to fully use own resources to cope with situations and tasks», that is, how «ability to perform a task or solve a problem», in any context, or as an exercise of «autonomy, responsability, ability to decide and to complete something» connected and the challenges it poses.

Then, this vision of competence distorts the traditional model of teacher education, based on the teaching of discipline, on the transmission of knowledge, often only disciplinary, and on the mnemonic exercise of the same to introduce a system of mastery of knowledge and competences, which implies the deep involvement and protagonism of the person learning and the motivations for which he learns. This vision, moreover, implies the opening of the school to any level in the world, to the real context that surrounds the learner, with the related problems that it involves and that personally involve the person.

Today, therefore, a renewed effort is needed, systematic and unique, to train teachers of every order and grade of school, which transforms them from «transmitters 
of knowledge» to «knowledge builders» through the development of a vertical curriculum for competences. The future of entire generations of young people is at stake, and they must learn at school to act and intervene in an increasingly complex and changing society with a wealth of skills.

It is necessary, therefore, to set up training plans that bring knowledge closer to competence, in terms of significance, that favour the approach to reality tasks and that make the solution of reality problems experiment. To better understand the term of competence and its function in the training intervention, we can say that skills are a set of knowledge and skills, supported by motivations consistent with the context of reference, necessary to accomplish or solve complex tasks and problems.

In the structure of the competence, as Pellerey $(2000,2004,2007)$ appropriately emphasizes, there are three components:

- cognitive nature, relating to the understanding of concepts;

- operational nature, involving the ability to apply knowledge;

- affective-motivational nature, involving the attitudes and motivations of the subject.

If this is true, it follows that, in order to set up an effective educational action, which wants to produce learning and competence in the subject/person, it is appropriate to act on all three components. It is necessary that, whatever is the training activity and the age group, the teacher has to act adequately in order to exercise skills related to a given competence, acquire the theoretical contents underlying it, encourage the understanding of the meaning and usefulness of related knowledge and skills, so that the person involved feels motivated to exercise it whenever the context so requires.

The result is that there is no competence without knowledge and that knowledge is the basis for building a conscious and meaningful competence. If, therefore, the teacher constantly encourages learners to reflect on the structural aspects of each task, to exercise comparison by looking for similarities and differences, to transfer as much as possible of what he has learned in new contexts, this model of work and learning will become a «habitus» and it will facilitate the acquisition of new skills and the transfer of these skills to other contexts.

Analysis of recent research and publications. The studies about language competences focus, first of all, on the role of the teacher who has essentially a role of mediation, support, and, if necessary, an advisory role in the formation of the person, the citizen and the worker. This role must be played by the teacher from the school of childhood, because it is by observing the teacher that the child learns to relate with others, to feel accepted and valued for what he/she is and what he/she can give. Then, the teacher has a great responsibility for the future formation of the learners and for their present and future attitude towards formation.

In fact, it can be said that much of the future of training and the success or failure of each person is already being determined in the early years of training, at the level of children's and primary education, that is, when the concept of self is structured 
and consolidated, which is based on the estimation of its SELF-EFFECTIVENESS, which since childhood is accompanied by success/failure experiences with reference to significant figures (Bandura, 2000, 1996).

The teacher who consciously designs and works by skills implies that any experience/training situation, in order to be truly metabolized, transformed into competence and become usable, must involve mind, heart, body and be re-read according to categories of meaning that consider both the external and the internal world and their mutual interconnections (Gardner, 2007, 1999, 1989). Many studies and research, in fact, have shown that «skills» and «motivation to learn» develop and consolidate in primary education, that is the role of basic training, as a prerequisite for further and higher education, is essential and irreplaceable, because acting in the choices and modes of learning of students at upper secondary level can be late and with uncertain results.

What are the main competences that we could define for the life that every teacher, whatever the discipline of teaching, must learn how to promote in his students? First of all, the development of transversal competences for life, which are:

- to know oneself;

- to manage emotions;

- to control tensions;

- to analyse/evaluate situations;

- to take decisions;

- to solve problems;

- to deal with every situation with adequate motivation;

- to express itself effectively;

- to understand the others;

- to interact positively.

In order to promote and support the development of skills in learners, the teacher must learn to identify the demand and training needs of each one, working to strengthen choice skills, decision making and self-assessment of the person (empowerment), be able to design training paths that respond to the demand and needs strengthening formal, informal and non-formal models of learning, with respect with the emotional states of each.

This implies a planning that develops through educational and training activities coherent with the subjects, in order to develop a personal and autonomous way of thinking and acting and a method that has a formative value for the acquisition of new skills (Cotton et al. 2007).

Presenting main material. Companies operating internationally have to interact with customers in many different countries, whose mother tongue will often not be the same. Language training is obviously useful in these situations: should it be compulsory in companies (Crystal, 1989)?

Essentially, in today's globalized economy, every company is international. Companies that have organized and structured language training plans have a 
competitive advantage over those that have training in the specific language of their employees. Although many companies today encourage their employees to learn foreign languages, of course, those companies that invest in language training through diversified solutions and projects have a return on tangible investment: the result can be seen in the end of the year in the greater entrances regarding companies that hope that the single employee «deepens the language and studies for its facts» (Hulstrand, 2008).

Language training has a «Return of Investment» (ROI) for companies, but it also increases earnings for the self-employed. Some surveys show that employers offering language courses see a sharp increase in revenue. This is particularly important in today's economy, where businesses are often run in multiple languages. Since a large majority of companies need to communicate in at least two languages, training of employees is not only useful, but becomes a duty to do continuing training in order not to lose the competitive advantage. If companies need advanced language skills, but they do not provide the workforce with the appropriate means to acquire the language skills needed to communicate (and sell your services or products), it will be almost obvious that these farms will be very disadvantaged compared to their competitors in the market (Hulstrand, 2008).

Recent studies have shown that the employees who are part of organizations with plans of development and business formation want to remain in a company organized from a point of view of the training compared to others without structured plans. Companies can capitalize on training, increasing their commitment to providing training and development programmes for employees. Companies must, of course, make financial investments.

A trained workforce has the skills necessary to be effective and efficient in its work. Competent employees determine the company growth. However, many essential skills for different roles and tasks need to be developed within the company itself because the secondary education does not prepare for specific fields. Having an inhouse training program at your company, it will help build critical skills in your staff, and ensure that daily operations are carried out smoothly. Corporate recruiters are well aware that an in-house business training plans becomes a key element to make their companies truly appealing to talent. Therefore, companies that offer these growth and development opportunities become very attractive to the potential workforce of tomorrow.

It is now imperative that employees are able to communicate effectively with their international clients and partners. Mastering a second language could lead to new leadership opportunities in international organizations (Hulstrand, 2008).

Access to an effective structured language training programme is an incentive for potential future corporate talent. It provides a concrete reason to choose one'company rather than another in finding a new job. 
Conclusion. In summary, the key points for an effective training are:

- The personalization of the formation and the formative participations;

- Active involvement;

- Design for skills;

-The development of a vertical curriculum;

- The conscious role of intermediation and support for trainee;

- The connection with reality and the world of work;

- Active training.

These are the prerequisites for a well-founded and lasting learning for the development of skills and attitudes, as well as for reflection and awareness.

The centrality of the person in the formative action means that the trainer with his individuality and diversity (age, gender, social and cultural belonging, values, aspirations, attitudes, etc.) is at the core of educational act and represents the core of training action as a whole.

The person, in a formative process, must be enabled to build and acquire skills that can accompany him/her in the various moments of his/her life and facilitate $\mathrm{him} / \mathrm{her}$ in making reasoned and conscious choices. The development of a vertical curriculum implies the overcoming of fragmentation and segregation of orders and grades of school according to a unitary formation which develops for degrees and levels and which uses disciplines in the instrumental, functional to formative learning. Therefore, discipline is not the purpose of training but the instrument at the service of training intervention.

Active and laboratory training means a teaching that is attractive and close to the needs of the learners, focussed on the operativity of the learning situations, the organization of learning pathways centred on the task, and using the classroom as a «laboratory», both as a well equipped physical place and as a moment where students design, construct artifacts and manipulate materials, predict, experiment, compare and discuss alongside the teacher mediator and guide.

This method, applicable to any discipline or field, starts from the data of the experience and the context that surrounds the learner who, in the laboratory, may be the class or the firm, where one learns to investigate, analyze, problematize, grasp cause and effect connections, compare, select, deduce, hypothesize, communicate, decide obtaining information, knowledge, but also procedures and cognitive models (Goleman, 1999, 1996). The workshop, where the trainee is an actor and protagonist, has a strong formative value and, therefore, also an orientation for his conjugating together knowledge and know-how, as well as for making concrete, real and effective learning.

A new model of initial and in-service training is necessary and no longer deferred, but it must be a vertical formation that includes some common modules for all levels and should be attentive to the development of the cognitive area and, no less important, to the emotional-relational and technological area. Today the technology, strongly advanced, offers opportunities and facilities in every field of learning, however flexible and adaptable to any need and training modality. 
Special attention should be given to the training of secondary school teachers at first grade. The junior high school is, in fact, an important junction for the choice of all the school and formative paths. It lays the foundations for the development of basic skills of a general nature, which should be acquired by the age of sixteen. The present moment requires a major investment in the training of teachers of all levels of education. It is not a question of acting with sporadic and piecemeal action of updating, but of acting with a systematic plan of training. It is a need and no longer deferrable investment, if we want our kids, future citizens and workers, be able to live in contexts of increasing complexity with a solid and amplified range of skills consistent with social, economic and labour changes.

\section{REFERENCES}

1. Appadurai A. (2001). Globalization. Durham (NC): Duke University Press.

2. Bandura A. (2000). Autoefficacia: Teoria e applicazioni. Trento, Erickson.

3. Bandura A. (1996), Il senso di Autoefficacia.Trento, Erickson.

4. Gardner H. (2007). Cinque chiavi per il futuro. Milano: Feltrinelli.

5. Gardner H. (1999). Sapere per comprendere. Milano: Feltrinelli.

6. Gardner H. (1989). Aprire le menti. Milano: Feltrinelli.

7. Cook, J. (2007). «Foreign language needs in today's business world». Retrieved July 20, 2009, from http://www.associatedcontent.com/article/222415/ foreign_language_needs_in_todays_business.html

8. Cotton, D., Falvey, D. \& Kent, S. (2007). «The keys to successful team building». In Market Leader, 71, p. 160.

9. Crystal, D. (eds.). (1989). The Cambridge Encyclopedia of Language. Cambridge: Cambridge University Press.

10. Goleman D. (1999). Lavorare con Intelligenza Emotiva. Milano: Rizzoli.

11. Goleman D. (1996). Intelligenza emotiva: Che cos'è, perché può renderci felici. Milano: Rizzoli.

12. Hulstrand, J. (2008). «Becoming proficient in a foreign language is becoming increasingly important to the global workforce in today's 'Flat' world». International Educator, September-October, 24-31.

13. Morin E. (2000). La testa ben fatta. Riforma dell'insegnamento e riforma del pensiero. Milano: Raffaello Cortina Editore.

14. Pellerey, M. (2007). Gli apprendimenti e le competenze di base, Provincia autonoma di Trento.

15. Pellerey, M. (2004). Le competenze individuali e il portfolio. Firenze: La Nuova Italia.

16. Pellerey, M. (2000). «Il portfolio formativo progressivo per la valutazione delle competenze». In Orientamenti pedagogici n. 5. 